UDC 517.988.38

\author{
V.P. Legeza*, O.V. Atamaniuk \\ Igor Sikorsky Kyiv Polytechnic Institute, Kyiv, Ukraine \\ *corresponding author: viktor.legeza@gmail.com
}

\title{
CURVE OF DESCENT OF A MATERIAL POINT IN THE SHORTEST TIME ON A TRANSCENDENTAL SURFACE IN A UNIFORM VERTICAL GRAVITATIONAL FIELD
}

Background. The article deals with the original variational problem of the brachystochronous motion of a material point on a cycloidal surface between two given points in a vertically homogeneous gravitational field. The novelty and relevance of the work is explained by the choice of the transcendental surface, since earlier the motion of a material point was considered on algebraic surfaces of the second order.

Objective. Find a curve on the transcendental surface, moving from one set point (starting point) to another set point (finish point) on this surface without friction a material point will make such a transition in a minimum time. The transcendental surface has a guide curve of the cycloid lying in one of the coordinate planes, and its generatrix are perpendicular to that plane.

Methods. To achieve this goal, we used the classical methods of variational calculus (Euler-Lagrange equation), as well as the classical method of integrating ordinary differential equations in a closed form (Bernoulli method).

Results. A time functional was constructed, using which the differential equations of the spatial brachystrochron, which lies on the transcendental surface, are analytically deduced. After integration in a closed form, algebraic equations of the spatial brachystrochron in parametric form are obtained. The results of the study are illustrated graphically: the projections of the trajectory of the brachystrochron on the coordinate planes $O X Y$ and $O X Z$. The slope angles of the optimal trajectory at the start point are determined. A comparative analysis of the time of action in the process of motion of a material point along two trajectories is carried out: along the obtained brachystrochron and along the alternative trajectory.

Conclusions. The proposed approach allows to pre-plot such a logistic route of a material point on a given transcendental surface between two fixed points, which will provide a minimum travel time between them in a uniform vertical gravity field. In this case, an extreme trajectory will not necessarily be the shortest line on the surface that connects the two predetermined points (start and finish).

Keywords: variational problem; brachystochronous motion; transcendental surface; time functional; cycloid; EulerLagrange equation; response time.

\section{Introduction}

This work is a continuation of scientific research [1-4], performed by the authors in the field of calculus of variations and related to the search for the equations of brachistochrone in various problem statements.

In articles [1, 2], the classical variational calculus methods were used to obtain the brachistochrone equations for a heavy uniform cylinder that rolls without sliding along a concave cylindrical recess, and the isochronism of its center of mass oscillations is proved.

A time functional was constructed in [3], using which the differential equation of the spatial brachistochrone, which lies on an inclined plane, is analytically derived. The algebraic equation of the brachistochrone is obtained, the results of the study are illustrated graphically. A comparative analysis of the speed for the optimal curve - brachistochrone - and two alternative ways of moving the material point.
In [4], the results of studying the brachistochrone motion of a material point in a horizontal vector field of a moving fluid are presented. The proposed approach makes it possible to lay the optimal logistic route, for example, of a motor boat, in a flat high-speed river flow between the given start and finish points, which ensures the minimum travel time between them.

We give a brief description of the results of work carried out in the framework of the scientific direction under consideration by other authors.

For the first time the problem of brachistochrone was posed and investigated by I. Bernoulli. In 1696, he formulated the following "brachistochrone problem": find the shape of the curve, moving along which a bead, which is at the initial moment in a resting position and accelerated by gravity, moves from one given point to another in the least amount of time. In this problem, it was assumed that the material point (bead) moves in a vertical 
plane in a uniform gravitational field without resistance.

I. Newton, V. Leibniz, G.F. Lopital, J. Bernoulli, I. Bernoulli showed that the cycloid is the solution to this problem [5].

Analytical solutions of the aforementioned "brachistochrone problem" with the classical use of the calculus of variations are presented in [6], and with respect to geometric optics, in [7].

Ashby et al. [8], Heijden and Diepstraten [9] investigated the problems of determining the shape of a brachistochrone taking into account coulomb friction forces during the motion of a material point in a vertical plane in a uniform gravitational field. In Lipp [10], the classical "brachistochrone problem" Bernoulli, taking into account dry friction, is transformed in terms of a control theory problem. In the new formulation of the brachistochrone problem, the time derivative of the angle that determines the direction of motion of the material point is a control parameter.

A generalization of the problem of searching for the shape of a brachistochrone that lies on an algebraic cylindrical surface, taking into account coulomb friction, was carried out by Covic and Veskovic [11]. Hayen [12], Vratanar, and Saje [13] investigated the problems of determining the shape of a brachistochrone in non-conservative force fields.

The problem of determining the shape of a brachistochrone on an algebraic cylindrical surface in uniform force fields was solved in the study [14], and on cylinders and spheres in the work of Palmieri [15].

A generalization of the problem of brachychistron to inhomogeneous fields was considered in articles Aravind [16], Denman [17] and Venezian [18], and in the last work the problem of brachistochrone in linear radial force fields was solved. Denman [17], Parnovsky [19], Tee [20] established solutions of the same problem in radial fields with a force dependence that is inversely proportional to the square of the distance between the interacting points.

Further generalizations of the brachistochrone problem for the material point at which relativistic effects were studied are presented in the works of Goldstein and Bender [21], Scarpello and Ritelli [22].

In the article by Gemmer [23], the problem of brachistochron was studied on algebraic surfaces of revolution with conservation of energy. For this, we use both the classical Euler-Lagrange equations and the method developed to solve a number of geometric optics problems on the propagation of a light beam. This article also studied the case of the motion of a material point with relativistic velocities.

In the article by Mertens and Mingramm [24], a new generalization of the brachistochrone problem is given, in which a curve is established that ensures the movement of a material point in a uniform gravitational field in the least amount of time between a given (starting) point and a given curve or between two given curves. Friction is not taken into account in these problems. A generalized problem is solved using variations with different endpoints (finish points). These problems belong to the field of variational problems with free boundary conditions.

The solution of the brachistochrone problem for a body of finite dimensions, which rolls over it without slipping, was known by Rodgers [25], however, in his work there is no rigorous derivation of the brachistochrone equations for this case.

The dynamic effects that occur when a uniform vertical disk moves along a horizontal plane without slipping were studied by Obradovic et al. [26].

In [27], a fluid dynamic version of the classical "Brachistochrone problem" by Bernoulli was considered. The problem of brachistochrone is posed, in which the material point is replaced by a cylinder filled with a viscous fluid. As part of its solution, a curve is established that connects two given points along which the cylinder moves in the shortest time. It is shown that in the general case the desired curve deviates from the cycloid. This is due to the fact that an increase in the rate of change in the kinetic energy of a cylinder with a liquid is accompanied by an increase in viscous energy dissipation.

The presented review of previous works published in this scientific field shows that the problems of finding brachistochrone for a material point in different settings were considered only on algebraic surfaces.

\section{Problem Statement}

In this paper, we consider the new problem of brachistochrone in the case of the motion of a material point on a transcendental surface in a vertical uniform gravitational gravitation field. The surface is a cut horizontal cylinder, the guiding curve of which is a cycloid, and the generators are parallel to the horizontal axis. Energy dissipation is not taken into account.

The purpose of the study: to find a curve on a transcendental surface, moving along which from one given point (start point) to another given point 
(finish point) of this surface, the material point will make such a transition in a minimum time.

\section{The construction of the time functional and the definition of the differential equation of brachist- ochrone}

Let introduce the spatial coordinate system as shown in Fig. 1. The parametric equations of the transcendental guide curve (cycloids) are determined by two coordinates $y(\theta)$ (ordinate) and $z(\theta)$ (applicate) of the material point:

$$
\left\{\begin{array}{l}
y(\theta)=R(\theta-\sin \theta) \\
z(\theta)=R(1+\cos \theta)
\end{array}\right.
$$

where $\theta$ - cycloid parameter, $\theta \in[0,2 \pi]$.

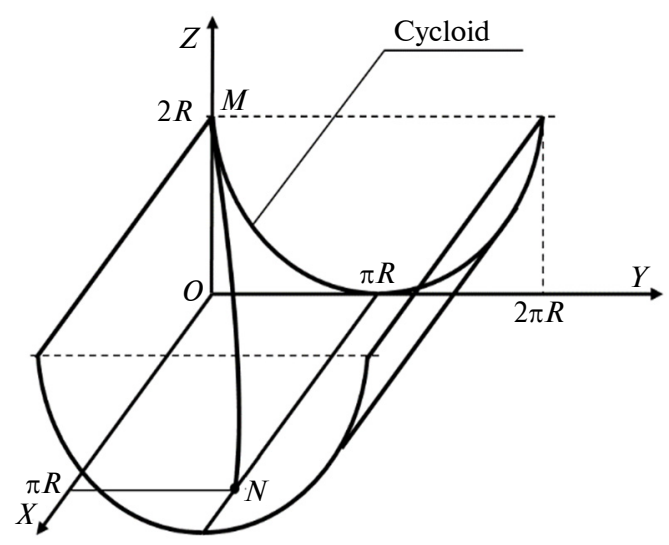

Fig. 1. The transcendental surface on which the brachistochrone movement of the material point

It is necessary to determine the dependence of the first coordinate $x$ on the parameter $\theta$ so that the spatial trajectory $L(\theta)=M N$ of the material point would provide a minimum of the time functional when it moves along the transcendental surface from point $M$ to point $N$.

Let the points mentioned above have the following coordinates: $M(x(0), y(0), z(0))-$ start and $N(x(\pi), y(\pi), z(\pi))$ - finish. If we take into account equations (1) and the boundary conditions for the abscissa $x(0)=0, x(\pi)=\pi R$, the coordinates of the start and finish points will be: $M(0,0,2 R)$ and $N(\pi R, \pi R, 0)$ (see Fig. 1). Let write the energy conservation equation for our problem:

$$
\frac{m v^{2}}{2}+m g z=h
$$

We define the constant $h$ in relation (2) taking into account the position of the starting point $M(0,0,2 R)$. In this case, at the starting point $M$ initial speed is zero $v=0$, and $z=2 R$. So we have:

$$
h=2 m g R \text {. }
$$

From relation (2) we obtain the expression for the velocity $v$ of a point on the surface:

$$
v=\frac{d s}{d t}=\sqrt{2 g} \cdot \sqrt{2 R-z}
$$

We write the expression for the differential of the arc $d s$ taking into account the holonomic constraint equations (1):

$$
\begin{aligned}
d s & =\sqrt{(d x)^{2}+(d y)^{2}+(d z)^{2}} \\
& =\sqrt{1+4 \sin ^{2}\left(\frac{\theta}{2}\right)\left(\theta_{x}^{\prime}\right)^{2}} d x .
\end{aligned}
$$

From equation (3), we express differentiation and write the time functional, which should be minimized:

$$
\left.T\right|_{L}=\frac{1}{2} \sqrt{\frac{1}{g R}} \int_{0}^{x_{f}} \frac{\sqrt{1+4 R^{2} \sin ^{2}(\theta / 2)\left(\theta_{x}^{\prime}\right)^{2}}}{\sin (\theta / 2)} d x,
$$

where $L-$ desired brachistochrone curve; $x_{f}(\pi)-$ the abscissa of the material point at the point corresponding to the parameter $\theta=\pi$.

We denote the integrand in functional (5) as $F\left(x, \theta(x), \theta^{\prime}(x)\right)$. So we have:

$$
F\left(x, \theta, \theta^{\prime}\right)=\frac{\sqrt{1+4 R^{2} \sin ^{2}\left(\frac{\theta}{2}\right)\left(\theta_{x}^{\prime}\right)^{2}}}{\sin \left(\frac{\theta}{2}\right)} .
$$

In this case, the classical Euler differential equations are used to determine the equations of the desired trajectory [2]:

$$
F_{\theta}^{\prime}-\frac{d}{d x}\left(F_{\theta^{\prime}}^{\prime}\right)=0
$$

Let's identify corresponding partial derivatives, which are displayed in (7). Let's write $F_{\theta}^{\prime}$ :

$$
F_{\theta}^{\prime}=\frac{-\cos \left(\frac{\theta}{2}\right)}{2 \sin ^{2}\left(\frac{\theta}{2}\right) \sqrt{1+4 R^{2} \sin ^{2}\left(\frac{\theta}{2}\right)\left(\theta_{x}^{\prime}\right)^{2}}} .
$$

Now let's define $F_{\theta^{\prime}}^{\prime}$ : 


$$
F_{\theta^{\prime}}^{\prime}=\frac{4 R^{2} \sin \left(\frac{\theta}{2}\right) \cdot \theta_{x}^{\prime}}{\sqrt{1+4 R^{2} \sin ^{2}\left(\frac{\theta}{2}\right)\left(\theta_{x}^{\prime}\right)^{2}}}
$$

Let's define $\frac{d}{d x}\left(F_{\theta^{\prime}}^{\prime}\right)$ :

$$
=\frac{\frac{d}{d x}\left(F_{\theta^{\prime}}^{\prime}\right)}{\left(1+4 R^{2} \sin ^{2}\left(\frac{\theta}{2}\right)\left(\theta_{x}^{\prime}\right)^{2} \cdot \cos \left(\frac{\theta}{2}\right)+2 \sin \left(\frac{\theta}{2}\right) \cdot \theta_{x x}^{\prime \prime}\right]} .
$$

We substitute expressions (8) and (10) into the Euler equation (7). As a result of elementary transformations, we obtain a second-order differential equation with the corresponding boundary conditions:

$$
\begin{gathered}
8 R^{2} \sin ^{3}\left(\frac{\theta}{2}\right) \cdot \theta_{x x}^{\prime \prime} \\
+8 R^{2} \sin ^{2}\left(\frac{\theta}{2}\right) \cos \left(\frac{\theta}{2}\right) \cdot\left(\theta_{x}^{\prime}\right)^{2}+\cos \left(\frac{\theta}{2}\right)=0, \\
x(0)=0, x(\pi)=\pi R .
\end{gathered}
$$

Equation (11) describes the dependence of the abscissa $x$ moving point as a function of parameter $\theta$. Let's define the dependence $x=x(\theta)$ taking into account given boundary conditions. By attaching the received function $x=x(\theta)$ to the equations of the guiding curve (1), we define a parametrized brachistochrone $L(\theta)$, which as many points $K$, described as:

$$
L(\theta)=\{K(x(\theta), y(\theta), z(\theta))\},
$$

where $\theta-$ parameter, $\theta \in[0, \pi]$.

The resulting equation (11) is integrated in quadratures. Show it.

Dependency definition $x=x(\theta)$.

Since the variable $x$ in the equation (11) not explicitly included, then a replacement can be made: $\left(\theta_{x}^{\prime}\right)^{2}=p(\theta)$, then

$$
2 \theta_{x x}^{\prime \prime} \theta_{x}^{\prime}=(p(\theta))_{\theta}^{\prime} \cdot \theta_{x}^{\prime} \Rightarrow \theta_{x x}^{\prime \prime}=\frac{1}{2}(p(\theta))_{\theta}^{\prime} .
$$

Substitution (12) turns equation (11) into a linear first-order equation:

$$
\begin{aligned}
& 4 R^{2} \sin ^{2}\left(\frac{\theta}{2}\right) \cdot \operatorname{tg}\left(\frac{\theta}{2}\right)\left(p(\theta)_{\theta}^{\prime}\right. \\
& +8 R^{2} \sin ^{2}\left(\frac{\theta}{2}\right) \cdot p(\theta)=-1
\end{aligned}
$$

Equation (13) is integrated using Bernoulli permutation:

$$
p(\theta)=u(\theta) \cdot v(\theta)
$$

We rewrite equation (13) taking into account the Bernoulli substitution:

$$
\begin{gathered}
4 R^{2} \sin ^{2}\left(\frac{\theta}{2}\right) \cdot \operatorname{tg}\left(\frac{\theta}{2}\right)\left(u^{\prime} v+u v^{\prime}\right) \\
+8 R^{2} \sin ^{2}\left(\frac{\theta}{2}\right) \cdot u \cdot v=-1 .
\end{gathered}
$$

We divide equation (14) into two equations, each of which can be integrated explicitly:

$$
\begin{gathered}
4 R^{2} \sin ^{2}\left(\frac{\theta}{2}\right) \cdot \operatorname{tg}\left(\frac{\theta}{2}\right) v^{\prime} \\
+8 R^{2} \sin ^{2}\left(\frac{\theta}{2}\right) \cdot v=0 \\
4 R^{2} \sin ^{2}\left(\frac{\theta}{2}\right) \cdot \operatorname{tg}\left(\frac{\theta}{2}\right) u^{\prime} v=-1 .
\end{gathered}
$$

Equation (15) after integration gives the function $v(\theta)$ :

$$
v(\theta)=\left(\sin \left(\frac{\theta}{2}\right)\right)^{-4} .
$$

Equation (16), after substituting (17) and integrating, gives the function $u(\theta)$ :

$$
u(\theta)=\frac{\cos \theta}{8 R^{2}}+C_{1} .
$$

Using expressions (17) and (18), we determine the solution of equation (13):

$$
p(\theta)=u(\theta) v(\theta)=\left(\sin \left(\frac{\theta}{2}\right)\right)^{-4}\left(\frac{\cos \theta}{8 R^{2}}+C_{1}\right) .
$$

We write the differential equation for $\theta_{x}^{\prime}$ :

$$
\frac{d \theta}{d x}=\sqrt{p(\theta)}=\left(\sin \left(\frac{\theta}{2}\right)\right)^{-2} \cdot \sqrt{\frac{\cos \theta}{8 R^{2}}+C_{1}} .
$$

Now we can determine the desired dependence $x=x(\theta)$ in quadratures: 


$$
x(\theta)=\int_{0}^{\theta} \frac{\sin ^{2}\left(\frac{t}{2}\right) d t}{\sqrt{\frac{\cos t}{8 R^{2}}+C_{1}}}+C_{2} .
$$

Further, for definiteness and simplification of further calculations, the characteristic value $R$ of cycloid we take equal to unity: $R=1$.

Given the boundary conditions in equation (11), we define arbitrary constants $C_{1}$ and $C_{2}$. It's obvious that $C_{2}=0$, and constant $C_{1}$ was determined from the transcendental equation

$$
\int_{0}^{\pi} \frac{\sin ^{2}\left(\frac{t}{2}\right) d t}{\sqrt{\frac{\cos t}{8}+C_{1}}}=\pi
$$

using numerical methods we get: $C_{1}=0,3222$.

So the expression $x(\theta)$ becomes final:

$$
x(\theta)=\int_{0}^{\theta} \frac{\sin ^{2}\left(\frac{t}{2}\right) d t}{\sqrt{\frac{\cos t}{8}+C_{1}}}, C_{1}=0,3222 .
$$

To illustrate, we give graphs of the projections of the found curve $L(\theta)$ taking into account equations (1) and (20) on the planes $O X Y$ and $O X Z$. Curve projection $L(\theta)$ onto the plane $O Y Z$ coincides with cycloid (1). When plotting, the characteristic of the cycloid $R$ was also chosen equal to unity.

Fig. 2 shows a graph of the projection of a curve $L(\theta)$ onto the plane $O X Y$. The tangent of this projection curve $L(\theta)$ relative to the axis $O X$ at the starting point (i.e., at $\theta=0$ ) is:

$$
\left.\frac{d y}{d x}\right|_{\theta=0}=2 \sqrt{\frac{1}{8}+C_{1}}=1,337 .
$$

Note that this graph is close to a straight line $y=x$, but does not match her.

Fig. 3 shows a graph of the projection of the curve $L(\theta)$ onto the plane $O X Z$. The tangent of this curve projection $L(\theta)$ relative to the axis $O X$ at the starting point is:

$$
\left.\frac{d z}{d x}\right|_{\theta=0}=-\infty .
$$

In other words, at the starting point, the motion graph in the plane $O X Z$ of the material point has a slope equals to $-\frac{\pi}{2}$, so the point begins its movement strictly vertically down.

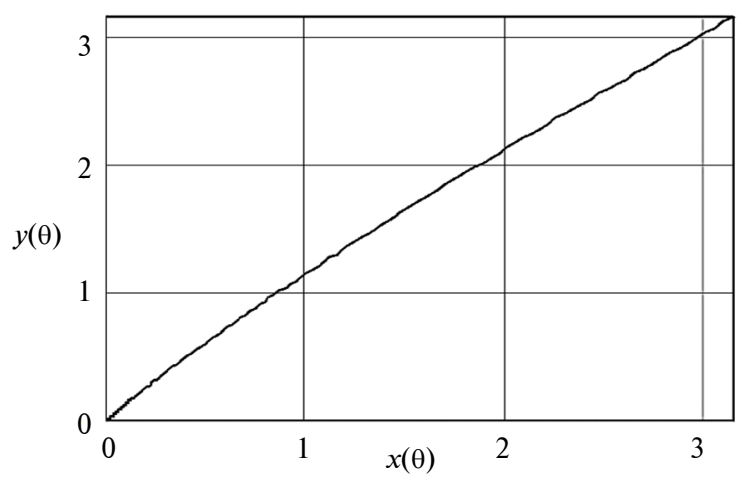

Fig. 2. The graph of the projection of a curve $L(\theta)$ onto the plane $O X Y$

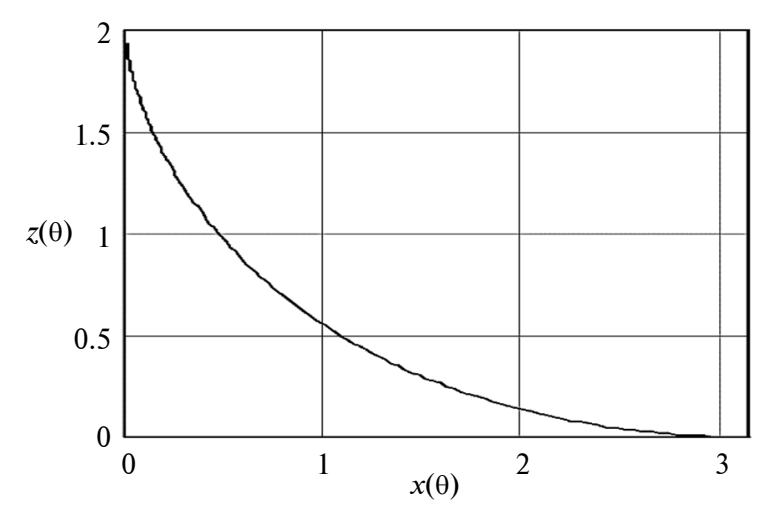

Fig. 3. The graph of the projection of the curve $L(\theta)$ onto the plane $O X Z$

\section{Determination of response time during brachisto- chrone movement of a point}

Let's write the expression for the differential $d x$ :

$$
d x=\frac{\sin ^{2}\left(\frac{\theta}{2}\right)}{\sqrt{\frac{\cos \theta}{8 R^{2}}+C_{1}}} .
$$

We substitute expression (21) into formula (5) for the response time $T$. After some transformations we get:

$$
\begin{aligned}
\left.T\right|_{L} & =\sqrt{\frac{R}{g}} \int_{0}^{\pi} \sqrt{\frac{1+8 R^{2} \cdot C_{1}}{\cos \theta+8 R^{2} \cdot C_{1}}} d \theta, \\
C_{1} & =0,3222, g \approx 9,81 \mathrm{~m} / \mathrm{c}^{2} .
\end{aligned}
$$


By numerical methods we determine the response time for $R=1$ :

$$
\left.T\right|_{L}=1,218 \text { (units of time). }
$$

Now for comparison, we calculate the motion time (response time) of the material point on an alternative curve $L_{1}$. It lies on the same cycloidal surface and connect the same given starting point $M$ (parameter $\theta_{s t}=0$ ) and finishing point $N$ (parameter $\theta_{f}=\pi$ ). It is formed as follows. Let its projection onto the plane be a straight line that connects the projections of the given start $M$ and finish $N$ finish points on the coordinate plane $O X Y$. In this case, the coordinates $x$ and $y$ will be related by the ratio $x=y$. Ordinate $y(\theta)$ and applicate $z(\theta)$ remain the same as in the optimal case.

As a result, the coordinates of the current point $K$, that lies on an alternative curve $L_{1}$, will have the following parametric form:

$$
L_{1}=\{K(R(\theta-\sin \theta) ; R(\theta-\sin \theta) ; R(1+\cos \theta))\} .
$$

Given the above functional time $T$ on curve $L_{1}$ after some transformations it will look like this:

$$
\left.T\right|_{L_{1}}=\sqrt{\frac{R}{g}} \int_{0}^{\pi} \sqrt{1+\sin ^{2}\left(\frac{\theta}{2}\right)} \cdot d \theta
$$

Let's calculate the last integral for $R=1$ :

$$
\left.T\right|_{L_{1}} \approx 1,220 \text { (units of time). }
$$

We see that the response time when moving a material point along an alternative curve $L_{1}$ is greater than along the brachistochrone curve $L$.

\section{Conclusions}

The problem of brachistochrone on a transcendental surface was first posed and solved in the work. The motion of a material point was considered in a vertical uniform gravitational gravitational field without taking into account energy dissipation. The surface is a cut horizontal cylinder, the guiding curve of which is a cycloid, and the generators are parallel to the horizontal axis. A time functional is constructed, with the help of which the classical Euler-Lagrange equations are derived analytically and in a closed form the parametric equations of spatial brachistochrone. To illustrate, graphs of the projections of the brachistochrone on the coordinate planes $O X Y$ and $O X Z$ are shown. The angles of inclination of the brachistochrone at the starting point are determined. A comparative analysis of the values of the response time functional for the obtained brachistochrone and an alternative trajectory of a material point along the surface.

Further scientific developments will be aimed at solving the problem of the brachistochrone motion of a material point on the considered transcendental surface, taking into account energy dissipation.

The results will interest experts in the field of applied mathematics and mechanics, calculus of variations, logistics and transport communications, geodesy.

\section{References}

[1] V.P. Legeza, "Cycloidal pendulum with a rolling cylinder", Mechanics of Solids, vol. 47, no. 4, pp. 380-384, 2012. doi: $10.3103 / \mathrm{S} 0025654412040024$

[2] V.P. Legeza, "Brachistochrone for a rolling cylinder", Mechanics of Solids, vol. 45, no. 1, pp. 27-33, 2010. doi: $10.3103 / \mathrm{s} 002565441001005 \mathrm{x}$

[3] V.P. Legeza and S.G. Savchuk, "Brachistochronous motion of the material point on an inclined plane a uniform gravitational field”, KPI Science News, no. 2, pp. 15-23, 2019. doi: 10.20535/kpi-sn.2019.2.167495

[4] V.P. Legeza and O.V. Atamaniuk, "The Brachistochronic movement of a material point in the horizontal vector field of a mobile fluid”, KPI Science News, no. 3, pp. 44-51, 2019, doi: 10.20535/kpi-sn.2019.3.175735

[5] W. Dunham, Journey Through Genius. New York: Penguin Books, 1991, 304 p.

[6] L.P. Eltsgolts, Differential Equations and Variational Calculus. Moscow, SU: Nauka, 1974, 432 p.

[7] H. Erlichson, "Johann Bernoulli's brachistochrone solution using fermat's principle of least time", Eur. J. Phys., vol. 20, no. 5, pp. 299-304, 1999. doi: 10.1088/0143-0807/20/5/301

[8] N. Ashby et al., "Brachistochrone with Coulomb friction", Am. J. Phys., vol. 43, no. 10, pp. 902-906, 1975. doi: 10.1119/1.9976

[9] A.M.A. van der Heijden and J.D. Diepstraten, "On the brachistochrone with dry friction", Int. J. Non-Linear Mechanics, vol. 10, no. 2, pp. 97-112, 1975. doi: 10.1016/0020-7462(75)90017-7

[10] S. Lipp, "Brachistochrone with Coulomb friction", SIAM J. Control Optim., vol. 35, no. 2, pp. 562-584, 1997. doi: $10.1137 / \mathrm{S} 0363012995287957$ 
[11] V. Covic and M. Veskovic, "Brachistochrone on a surface with Coulomb friction”, Int. J. Non-Linear Mechanics, vol. 43, no. 5, pp. 437-450, 2008. doi: 10.1016/j.ijnonlinmec.2008.02.004

[12] J.C. Hayen, "Brachistochrone with Coulomb friction”, Int. J. Non-Linear Mechanics, vol. 40, no. 8, pp. 1057-1075, 2005. doi: 10.1016/j.ijnonlinmec.2005.02.004

[13] B. Vratanar and M. Saje, "On analytical solution of the brachistochrone problem in a non-conservative field", Int. J. NonLinear Mechanics, vol. 33, no. 3, pp. 489-505, 1998. doi: 10.1016/S0020-7462(97)00026-7

[14] H.A. Yamani and A.A. Mulhem, "A cylindrical variation on the brachistochrone problem", Am. J. Phys., vol. 56, no. 5, pp. 467-469, 1988. doi: 10.1119/1.15755

[15] D. Palmieri, "The brachistochrone problem, a new twist to an old problem”, Undergraduate Honors Thesis, Millersville University of PA, 1996

[16] P.K. Aravind, "Simplified approach to brachistochrone problem", Am. J. Phys., vol. 49, no. 9, pp. 884-886, 1981. doi: $10.1119 / 1.12389$

[17] H.H. Denman, "Remarks on brachistochrone-tautochrone problem", Am. J. Phys., vol. 53, no. 3, pp. 224-227, 1985. doi: $10.1119 / 1.14125$

[18] G. Venezian, "Terrestrial brachistochrone”, Am. J. Phys., vol. 34, no. 8, p. 701, 1966. doi: 10.1119/1.1973207

[19] A.S. Parnovsky, "Some generalisations of the brachistochrone problem", Acta Physica Polonica, Suppl. A 93, pp. 5-55, 1998.

[20] G. Tee, "Isochrones and brachistochrones", Neural, Parallel Sci. Comput., vol. 7, pp. 311-342, 1999.

[21] H.F. Goldstein and C.M. Bender, "Relativistic brachistochrone", J. Math. Phys., vol. 27, no. 2, pp. 507-511, 1986.

[22] G.M. Scarpello and D. Ritelli, "Relativistic brachistochrone under electric or gravitational uniform field", Z. Angew. Math. Mech., vol. 86, no. 9, pp. 736-743, 2006. doi: 10.1002/zamm.200510279

[23] J. Gemmer et al., "Generalizations of the brachistochrone problem", Pi Mu Epsilon J., vol. 13, no. 4, pp. 207-218, 2011.

[24] S. Mertens and S. Mingramm, "Brachistochrones with loose ends", Eur. J. Phys., vol. 29, pp. 1191-1199, 2008. doi: $10.1088 / 0143-0807 / 29 / 6 / 008$

[25] E. Rodgers, "Brachistochrone and tautochrone curves for rolling bodies", Am. J. Phys., vol. 14, pp. 249-252, 1946. doi: $10.1119 / 1.1990827$

[26] A. Obradovic et al., "The brachistochronic motion of a vertical disk rolling on a horizontal plane without slip", Theor. Appl. Mech., vol. 44, no. 2, pp. 237-254, 2017. doi: 10.2298/TAM171002015O

[27] S.S. Gurram et al., "On the brachistochrone of a fluid-filled cylinder", J. Fluid Mech., vol. 865, pp. 775-789, 2019. doi: $10.1017 / \mathrm{jfm} .2019 .70$

\section{В.П. Легеза, О.В. Атаманюк}

КРИВА СПУСКУ МАТЕРІАЛЬНОЇ ТОЧКИ ЗА НАЙМЕНШИЙ ЧАС ПО ТРАНСЦЕНДЕНТНІЙ ПОВЕРХНІ В ОДНОРІДНОМУ ВЕРТИКАЛЬНОМУ ГРАВІТАЦІЙНОМУ ПОЛІ

Проблематика. В статті розглядається оригінальна варіаційна задача про брахістохронний рух матеріальної точки на циклоїдальній поверхні між двома заданими точками у вертикальному однорідному гравітаційному полі. Новизна і актуальність роботи пояснюються вибором трансцендентної поверхні, оскільки раніше рух матеріальної точки розглядався на алгебричних поверхнях другого порядку.

Мета дослідження. Знайти криву на трансцендентній поверхні, рухаючись по якій від однієї заданої точки (точки старту) до іншої заданої точки (точки фінішу) по цій поверхні без тертя матеріальна точка здійснить такий перехід за мінімальний час. Трансцендентна поверхня має за напрямну криву циклоїду, що лежить в одній із координатних площин, а їі твірні перпендикулярні цій площині.

Методика реалізації. Для досягнення зазначеної мети в роботі використовувались класичні методи варіаційного числення (рівняння Ейлера-Лагранжа), а також класичний метод інтегрування звичайних диференціальних рівнянь (метод Бернуллі).

Результати дослідження. Побудовано функціонал часу, з використанням якого аналітично виведено диференціальні рівняння просторової брахістохрони, що лежить на трансцендентній поверхні. Після інтегрування в замкненій формі отримано алгебричні рівняння просторової брахістохрони у параметричній формі. Результати дослідження проілюстровано графічно: наведено проекції траєкторії брахістохрони на координатні площини OXY і OXZ. Визначено кути нахилу оптимальної траєкторії у точці старту. Наведено порівняльний аналіз часу швидкодії в процесі руху матеріальної точки вздовж двох траєкторій: вздовж брахістохрони та вздовж альтернативної траєкторії.

Висновки. Запропонований підхід дає змогу наперед прокласти такий логістичний маршрут матеріальної точки на заданій трансцендентній поверхні між двома фріксованими точками, який забезпечить мінімальний час переміщення між ними в однорідному вертикальному полі тяжіння. В цьому разі екстремальною траєкторією не обов'язково буде найкоротша лінія, яка лежить на поверхні і з'єднує дві задані точки (старту і фінішу).

Ключові слова: варіаційна задача; брахістохронний рух; трансцендентна поверхня; функціонал часу; циклоїда; рівняння Ейлера-Лагранжа; час швидкодії. 
В.П. Легеза, О.В. Атаманюк

\section{КРИВАЯ СПУСКА МАТЕРИАЛЬНОЙ ТОЧКИ ЗА НАИМЕНЬШЕЕ ВРЕМЯ ПО ТРАНСЦЕНДЕНТНОЙ ПОВЕРХНОСТИ В ОДНОРОДНОМ ВЕРТИКАЛЬНОМ ГРАВИТАЦИОННОМ ПОЛЕ}

Проблематика. В статье рассматривается оригинальная вариационная задача о брахистохронном движении материальной точки на циклоидальной поверхности между двумя заданными точками в вертикальном однородном гравитационном поле. Новизна и актуальность работы объясняются выбором трансцендентной поверхности, так как ранее движение материальной точки рассматривалось на алгебраических поверхностях второго порядка.

Цель исследования. На трансцендентной поверхности найти кривую, двигаясь по которой от одной заданной точки (точки старта) к другой заданной точке (точке финиша) на этой поверхности без трения материальная точка осуществит такой переход за минимальное время. Трансцендентная поверхность в качестве направляющей кривой имеет циклоиду, которая лежит в одной из координатных плоскостей, а ее образующие перпендикулярны этой плоскости.

Методика реализации. Для достижения указанной цели в работе использовались классические методы вариационного исчисления (уравнение Эйлера-Лагранжа), а также классический метод интегрирования обыкновенных дифференциальных уравнений (метод Бернулли).

Результаты исследования. Построен функционал времени, с использованием которого аналитически выведены дифференциальные уравнения пространственной брахистохроны, которая лежит на трансцендентной поверхности. После интегрирования в замкнутой форме получены алгебраические уравнения пространственной брахистохроны в параметрической форме. Результаты исследования проиллюстрированы графически: приведены проекции траектории брахистохроны на координатные плоскости OXY и OXZ. Определены углы наклона оптимальной траектории в точке старта. Приведен сравнительный анализ времени быстродействия в процессе движения материальной точки вдоль двух траекторий: вдоль брахистохроны и вдоль альтернативной траектории.

Выводы. Предложенный подход позволяет заранее проложить такой логистический маршрут материальной точки на заданной трансцендентной поверхности между двумя фриксированными точками, который обеспечит минимальное время перемещения между ними в однородном вертикальном поле тяготения. В этом случае экстремальной траекторией не обязательно будет кратчайшая линия, которая лежит на поверхности и соединяет две заданные точки (старта и финиша).

Ключевые слова: вариационная задача; брахистохронное движение; трансцендентная поверхность; функционал времени; циклоида; уравнение Эйлера-Лагранжа; время быстродействия.

Рекомендована Радою

факультету прикладної математики

КПІ ім. Ігоря Сікорського
Надійшла до редакції 29 вересня 2019 року

Прийнята до публікації 31 жовтня 2019 року 